\title{
African Values for the Practice of Human Resource Management
}

\author{
Osarumwense Iguisi \\ Department of Business Administration, University of Benin, Nigeria
}

\begin{abstract}
The importance of cultural values for management practice in Africa has become increasingly obvious in recent years as many expectations of African organizations and institutions created and managed along lines of Western management assumptions, textbooks and models have not achieved the expected results of sustainable economic development and growth. In Africa, we have very limited knowledge about its cultural values and the consequences it poses for management practice in African organizations. The research project investigated some African traditional values in Nigerian work organizations. The research question that the study tries to address is: to what extent is the assumptions in Western management theories consistent with the African Traditional values for the practice of management in Africa? The research findings strongly suggests that the applicability of Western management assumptions in theories and models for motivating African workers from a high power distance and collectivistic societies is doubtful and suspect. The transplantation of Western management theories and models has not met the needs and aspirations of the peoples of Africa. The study suggests that elements of traditional values pose serious challenge to African managers' ability to adopt traditional and modern practices that can improve the effectiveness of $H R$ in their organizations.
\end{abstract}

Key Words: Management, Cultural Values, Traditional, Africa, Modern, Western

(C) 2014 Beykent University 


\section{Introduction}

Modern Africa suffers from a number of extremely unfortunate influences, such as tribal warfare, despotism, starvation, drought, HIV/AIDS and other epidemics that leads to economic decline. To outsiders, these problems seem fatal.

In most or all projections of economic development, Sub-Saharan African countries score poorly. Africa figures as the poor relative in the world family of nations and seems to be condemned to remain so for the foreseeable future. In official statistical data, Sub-Saharan African countries nearly always show up at the negative end. Where events become too dramatic, relief actions from wealthier nations interfere with African chaos. Such efforts are often also linked to the donor's own perceived political and economic interests and ignorant of African historical and cultural conditions. Therefore, these interventions rarely achieve any long-term improvement; they in some cases create or recreate dependence, helplessness and neo-colonialist relationships. Among several reasons for this dramatic situation, a lack of adequate and feasible indigenous management takes a prominent position. The noticeable lack of success of many African organizations created and managed according to western theories and models can be attributed, rightly or wrongly to this fact. Projects more or less function as long as they are managed by expatriate experts-who in doing so exceed their roles but they flounder after having been transferred to the locals.

While the African elite is very knowledgeable about accepted models and theories of the Western world, knowledge about cultural values of his or her society is limited. The African elite is not equipped enough to understand the obligations imposed on her/him by Western cultural values in which she/he has been socialized and the traditional environment in which she/he was born and raised, thus, making her/his ability to contribute something original to the development of her/his society limited.

Because of failure of the westernized African managers to identify and take advantage of the 'growthpositive' cultural values of their society for effective management practices that the relevancy of western management theories and models utilized in training managers in Universities and business schools to managing organizations in Sub-Saharan Africa comes into question.

Clearly Africa is not the nearest in culture to the western world, yet the continent has indeed been experiencing perhaps the fastest pace of westernization this century of anywhere in the non-western world. The colonial era in most of Africa has been one of the shortest in world history. Most countries of Africa below the Sahara have been exposed to Western colonial powers for less than a century before reverting to independence in the second half of the twentieth century. Before the colonialist came, Africa had functioning political, economic and administrative infrastructures. The old African towns and villages had effective public administrative systems, which the town and village heads, chiefs and kings administered. Great historical cities in Africa had mighty walls built around them; most villages, towns, and tribal groups had strong armies for their inter-tribal wars. Certainly the construction of these walls and maintenance of these armies must have involved a great deal of organizational and managerial activities. Africans must have had ways of organizing their world of work. They must have had a way of exercising power and authority at the workplace, a way of motivating and rewarding people to make them work harder. Neither 
the institutions nor the political boarders imposed by the colonizers have respected these infrastructures, but much of them have survived in village life and in the traditions and cultures of the African people. However, unlike in Europe and most part of Asia, the attempted modernization or Westernization after independence has completely neglected the native cultural traditions and tried to transfer or transplant ready-made western management theories and models to traditional African soil. The results of these transformations, in most cases, have been disastrous.

It has taken several decades for the western developers to realize the bankruptcy of technocratic models of development. Many projects are still started on the basis of unwarranted assumptions on the transferability of western management methods to African cultures. Works on the development of African models have been rare, and more focused on the political than on the industrial scene. A basic assumption to be made here is that suitable African management models can only be developed by Africans themselves, or at least in close collaboration with African practitioners and western suppliers of technology. There is limited literature on this topic by African authors, like Onyemelukwe (1973), Bourgoin (1984), Oshagbemi (1988) and Kigundu (1993), (Mbigi, 1997), (Boon, 1996), (Jackson, 1999, 2005), (Iguisi, 1994; 2012).

The objective of this paper is to draw attention to the relevance of cultural values with the purpose of contributing to a culturally viable and appropriate theories and practice of human resource management in Sub-Saharan Africa. Human Resource Management practice in Africa require identification of "growthpositive" and "growth-negative" culture-based factors.

This paper begins with definitions of culture and discusses the role of culture in management and then the specific characteristics of contemporary African cultures. The paper goes on to present some implicit cultural assumptions in western management theories, African cultures and modern management practices. The paper looks at the way forward for culture and management issues in Africa, and concludes with issues of harmonizing cultures with modern management practices in Africa.

\section{Literature Review}

\section{Culture Stabilization Patterns}

The model of Figure 1, taken from Iguisi and Hofstede (1993), indicates how we assume culture patterns in a country to stabilize themselves through feedback loops, but also to change under the influence of outside forces.

In the center is a system of societal norms, consisting of the value systems shared by major groups of the population. Their origins are in a variety of ecological factors (in the sense of factors affecting the physical environment). The societal norms have led to the development and pattern maintenance of institutions in society with a particular structure and way of functioning. These include the family, education systems, politics, and legislation. These institutions, once they have become facts, reinforce the societal norms and the ecological conditions that led to them. According to Hofstede, in a relatively closed society, such a system will hardly change at all. Institutions may change, but this does not necessarily affect the societal norms; and when these remain unchanged, the persistence influences of a majority value system patiently 
smooth the new institutions until their structure and functioning is again adapted to the societal norms. Change comes mainly from the outside, through forces of nature (change of climate, silting up of harbors) or forces of man (trade, colonization, scientific discovery) (Hofstede, 1980). The arrow of outside influences is deliberately directed at the origins, not at the societal norms themselves. It is believed that norms change rarely by direct adoption of outside values, but rather through a shift in ecological conditions: technological, economical, and hygienic. In general, the norm shift will be gradual unless the outside influences are particularly violent (Hofstede, 1980a).

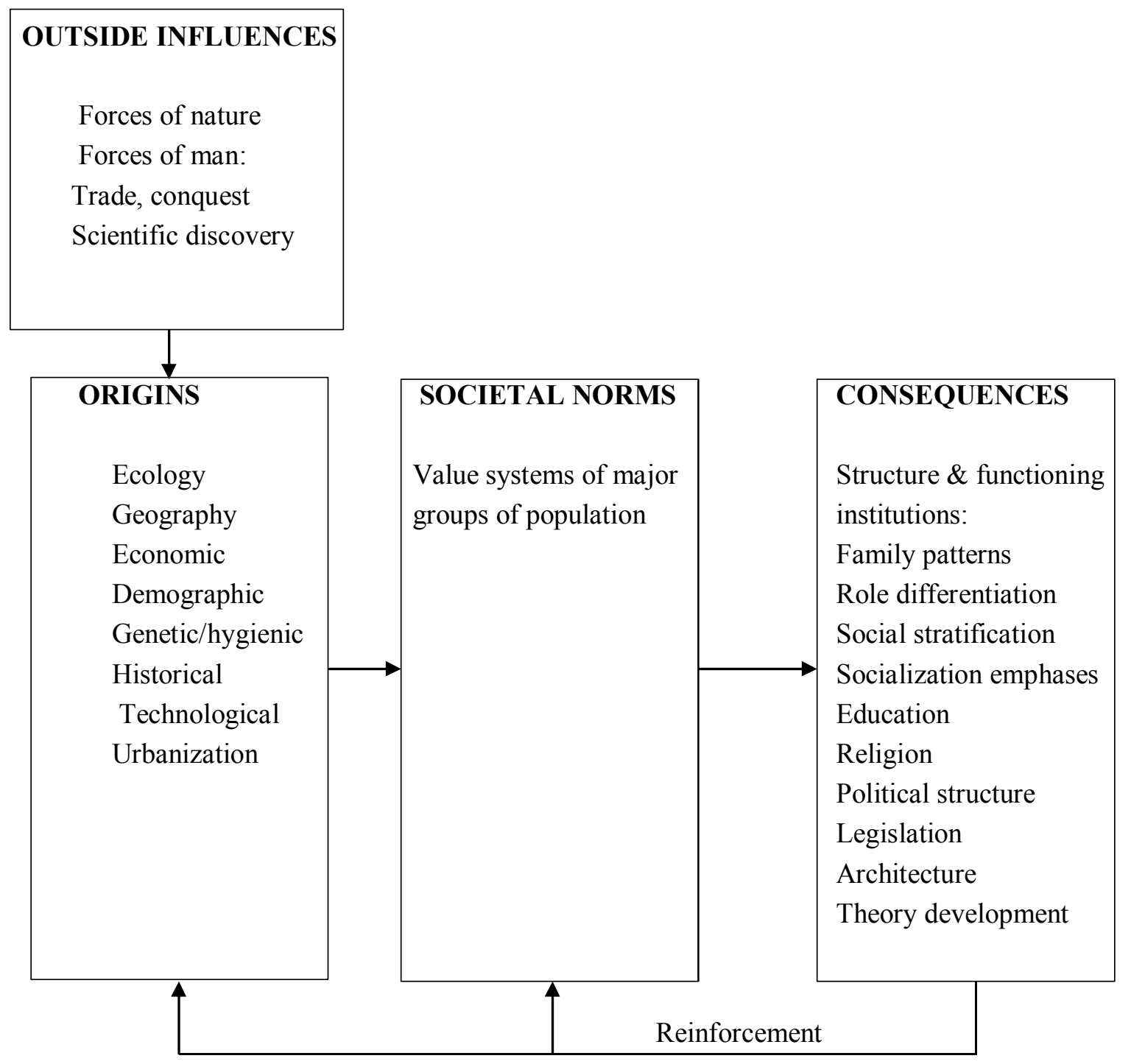

Figure 1: The stabilization of culture patterns (source: Iguisi and Hofstede, 1993:3)

The system of this model in Figure 1 implies that one cannot understand one element-such as, feasible management practices within the local environment-without its societal and cultural value context.

Culture and Value Defined 
The constituent elements of a culture consist of the whole complex of distinctive features that characterizes a society or social group. These features may be spiritual, intellectual, material or emotional (UNESCO, 1982).

Geert Hofstede (1980), a Dutch Professor of Social Anthropology defines culture as the "software of the mind", a collective phenomena, shared with the people who live in the same social environment. It is the collective programming of the mind, which distinguishes the members of one social group or category of people from another. It includes the society's institutions, legal system, method of government, family patterns, social conventions-all those activities interactions and transactions, which define the particular flavor of a society (Hofstede, 1991:5). According to Adler (in Blunt 1992: 189), 'the cultural orientation of a society reflects the complex interaction of the values, attitudes, and behaviors displayed by its members'.

Culture is to a human collectivity what personality is to an individual. Guilford (1959) defined personality as "the interactive aggregate of personal characteristics that influence the individual's response to the environment". Culture could be defined as the interactive aggregate of common characteristics that influence a human group's response to its environment. Culture determines the identity of a human group in the same way as personality determines the identity of an individual.

According to the UNESCO Declaration of 2001, culture "should be regarded as the set of distinctive spiritual, material, intellectual and emotional features of society or a social group, and that it encompasses, in addition to art and literature, lifestyles, ways of living together, value systems, traditions and beliefs." What constitutes culture then is the amalgamation of social practices, beliefs, and traditions that shape the outlook of the society.

The core of culture is formed by values. Values: are broad tendencies to prefer certain states of affairs over others. According to Hofstede (2012), Values are basic convictions that people have regarding what is right and wrong, good and bad, important or unimportant. Some values are related to relatively specific aspects of life-such as, what is socially appropriate behavior for people in different societies. Values are among the first thing children learn-not consciously, but implicitly.

\section{The Role of Culture in Management}

As comparative management scholars search for both similarities and differences between cultures, it may be useful to study not only perceptions about the way things are in a culture but also the way they ought to be.

The compelling need for clearly understanding the impact of culture on management per se is now mounting. For the past two decades, a number of researchers have investigated this issue. These investigations have culminated in ongoing debates between those who believe that management is a science governed by universal principles, the so-called "culture-free" or "universalist" school of thought, and those who argue that these principles are determined by a relative culture, the so-called "culture specific" or "culturalist" school of thought. 
The culturalist school had raised considerable doubt regarding the transferability of management methods and theories developed in one cultural society to another (Hofstede, 1980, 1991, 2007; Hunt, 1981; Iguisi, 1994, 2005, 2012). Advocates of this line of thinking argue that since societies exhibit distinct and persistent cultures, organizations in different social context are likely to experience the implication of such variations. Organization members from different cultures will differ in their needs for achievement, affiliation, security and self-actualization and these have close relationship to behavior within an organization. Societies differ in the norms and attitudes of people towards authority. Consequently subordinates from different societies will react differently to superiors and will experience different organizational rules considering rights and duties.

\section{Assumptions in Western Management Practice versus Management Values in African Cultures}

Management and development objectives and methods of achieving these objectives always carry with them cultural assumptions. The work of the formal organization and management theorists like Fayol, Taylor, Maslow, Herzberg, Likert and others were, for example, based on sociocultural norms of the society in which they were born, raised and lived. Thus their theories emphasized problems of clear definitions and responsibilities. Throughout their analysis the emphasis were on the individual accountability and on impersonal definition of functions therefore reflecting the individualistic culture of their societies as opposed to the collectivistic cultures of Sub-Saharan Africa societies. The failure of many African scholars and practicing managers to notice that theories of formal organization and management made social and cultural assumptions have left a hidden factor in the application of theories and models of formal organization and management.

According to Hofstede, (1991) ideas about leadership and decision-making have often been developed in the West, and most particularly in the USA, into package that can be exported into non-Western societies. Examples are management by objectives (MOB), Theory X and Theory Y, Achievement motives, system Y management etc. Almost without exception, the cultural assumptions that went into these packages have not been explored. What they all have in common is that they have all advocated participation in the leadership decisions by the subordinates (participative management). Nevertheless, these packages have been exported to other countries as magic recipes for management training, HR development and performance improvement.

There is no doubt that these authors did not take into account, the cultural values of the non-Western societies in their theories. This is especially the case of Africa. Respect for age and hierarchy means that superiors are expected to make decisions to be passed down to the subordinates; in fact this is expected. When leadership theories recommend that employees be made or encouraged to participate in decisionmaking and as such consultative or participative leadership style is judged to be the best. This may be true in Western societies of Europe and North America and may not be true in Africa. Many leadership packages like the Management By Objective (MBO)-which is based on joint goal setting between superior and subordinate, and joint appraisal against set goals on a periodic basis-may not be very feasible in Africa cultures. The assumptions in MBO is that the subordinates can freely and independently communicate with 
superiors and even act on their own initiative. Evidence from Ahiauzu (1985) study of some 145 Nigerian workers showed that desire for independent decision-making was only important to $8 \%$ of the sample in terms of factors which motivate them to higher performance. In large power distance societies like Africa, these assumptions do not fit culturally. The Western models of "participative" and "consultation" management do not or partly apply in African cultures. (Hofstede and Iguisi, 1993). (see Table 1)

Table 1. Types of managers preferred, actual and rejected across cultures

\begin{tabular}{|c|c|c|c|c|c|}
\hline $\begin{array}{l}\text { Leadership } \\
\text { styles }\end{array}$ & 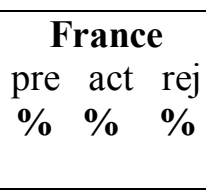 & 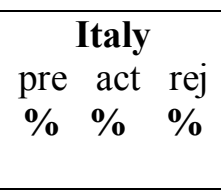 & $\begin{array}{l}\text { Scotland } \\
\text { pre act rej } \\
\% \% \% \%\end{array}$ & $\begin{array}{c}\text { Holland } \\
\text { pre act } \\
\text { rej } \\
\% \% \\
\%\end{array}$ & \begin{tabular}{l}
\multicolumn{2}{c}{ Nigeria } \\
pre \\
rej \\
\% $\% \quad \%$
\end{tabular} \\
\hline autocratic & 3576 & $\begin{array}{lll}5 & 28 & 66\end{array}$ & $\begin{array}{lll}10 & 35 & 52\end{array}$ & $\begin{array}{lll}0 & 12 & 71\end{array}$ & $\begin{array}{lll}7 & 31 & 60\end{array}$ \\
\hline paternalistic & $24 \quad 20$ & $\begin{array}{lll}30 & 34 & 1\end{array}$ & $27 \quad 31$ & $24 \quad 36$ & $\begin{array}{ll}40 & 39\end{array}$ \\
\hline consultative & $49 \quad 20$ & $\begin{array}{lll}48 & 32 & 11\end{array}$ & $52 \quad 25$ & $\begin{array}{ll}58 & 39\end{array}$ & $\begin{array}{c}3515 \\
18\end{array}$ \\
\hline democratic & $\begin{array}{lll}27 & 16 & 12\end{array}$ & $\begin{array}{c}17 \\
22\end{array}$ & $\begin{array}{lll}11 & 9 & \mathbf{3 8}\end{array}$ & $\begin{array}{lll}18 & 9 & 29\end{array}$ & $\begin{array}{c}18 \quad 14 \\
19\end{array}$ \\
\hline
\end{tabular}

Source: Author's own.

Figures presenting remarkable differences between the five countries are printed in bold.

pre $=$ Preferred act $=$ Actual $\quad$ rej $=$ rejected

Taking the case of Maslow's need theory, which he believes is arranged in a hierarchical order of importance from lower needs-physiological-to-highest needs-self-actualization, he believes that the individual achieve the highest, she/he is capable of achieving, is the top most important motivator. Looking at his assumptions, we might agree that this might be true in the Western societies of Europe and North America, but does not very well fit or partly applicable in African cultures. (Table $2 \& 3$ ).

Table 2. Relative importance of work goals across cultures

\begin{tabular}{|l|l|}
\hline Africa (Nigeria) & Europe (Netherlands) \\
\hline 1. Contribute & 1. Challenging job \\
2. Good boss & 2. Freedom \\
3. Relationship & 3. Living in desirable area \\
4. Helping others & 4. Consultation \\
5. Challenging job & 5. Cooperation \\
6. Serve your country & 6. Serve your country \\
\hline
\end{tabular}

Source: Author's own.

For most Africans, while it may be worthwhile self-achieving, individuals may not be regarded as such unless the society approves. There is a great deal of approval-seeking in the African cultures to the extent that people struggle to achieve not necessarily for themselves but for the satisfaction of the larger society 
which includes their immediate and extended families as depicted in Table 4. With Frederick Herzberg's Two Factor Theory, he believes that hygiene factor of interpersonal relations is not a motivator, while achievement and personal recognition are. This again might be true in Western cultures, African workers in a comparative study carried out by Iguisi (1994) reveals that affectionate relationships between superior and subordinate motivated them much more than recognized achievement, challenging work and participation in decision-making, all which are considered high motivators by Herzberg.

In the case of Manslow, Herzberg, McClelland, and Vroom's universal theories, human motivation is in fact a value choice in which the value system dominant in the western world is held up as model for the rest of the world. Their work is a reflection of the cultures prevailing in their sociocultural environment of low power distance and individualism.

Table 3. Rank-ordering of five most Important Work-goals by the Nigerian Respondents

\begin{tabular}{|l|c|c|}
\hline \multicolumn{2}{|c|}{ Goals ranked in need "hierarchy" } \\
\hline Goals & & \\
\hline High - Self Actualisation & Rank Order & Rank Order \\
and esteem needs: & Managers & Non-managers \\
\hline Challenging job & $\mathbf{2}$ & $\mathbf{3}$ \\
Stress & 17 & 17 \\
Freedom & 10 & 9 \\
Variety and Adventure & 16 & 16 \\
Living area & 9 & 11 \\
\hline Middle - Social needs & & $\mathbf{2}$ \\
& & $\mathbf{5}$ \\
Cooperation & $\mathbf{5}$ & 13 \\
Relationships with boss & 13 & 12 \\
Opportunity for helping others & 14 & $\mathbf{1}$ \\
Successful organisation & 11 & $\mathbf{4}$ \\
Serve your country & $\mathbf{1}$ & \\
\hline Low - Security and physiological needs & & \\
Security & $\mathbf{3}$ & \\
Earnings & & \\
Opportunity for higher level jobs & & \\
Physical conditions & & \\
Contribution & & \\
& & \\
\hline
\end{tabular}


The logical conclusion of the above assumptions is that African management must be stimulated from the assumptions of the cultures in which most of the theories were developed (the Western cultures), through transfer of ready-made Western management systems. The evidence to date strongly suggests that most of these assumptions are not or partially valid and not very appropriate in managing organizations in African cultures. The applicability of these management theories and models for motivating African workers from a high power distance and collectivistic societies is doubtful and suspect.

\section{Issues of Relevancy}

The transplantation of western management theories and models has not met the needs and aspirations of the peoples of Africa. We find that Africa South of the Sahara in spite of its claims to the contrary, has made a superficial acceptance of western management values and attitudes. The result is that the western approaches to management practices in Africa as prescribed by the Universalist school of thought has not made the contribution it could have made if there were effective assimilation of its prescriptions and standards. Elsewhere, the portrait of Africa is a bleak one of chilling consequences. For the continent is not catching up with the rest of the world, it is falling further behind (despite adoption and implementation of economic and management models of the west for Africa development). According to Lamb (1985), Africa is no longer part of the Third World; it is now the Fourth World.

It is truly disappointing to find that, despite all available evidences towards the role of culture in management for African scholars, leaders, managers, and international development agencies that have been prescribing western formula for African development to have not recognized that culture does have greater part to play in their consideration for management and economic development issues in Africa. (see Frank, Hofstede, and Bond, 1991; Hofstede, 2012; Iguisi, 1994, 1998, 2012; Boon, 2005),

One is amazed that in Africa, culture is nearly always relegated to the background in the public estimation of Africans' affairs. Prominence is given to politics, economics, bureaucracy and holders of public offices, no doubt deservedly; we are enthralled by the vagaries of the economy but hardly does the crucial role of cultures or lack of it, receive any appreciable mention in the serious consideration of African development affairs. Yet culture is so vital in the context of African development as one of the so-called Third World countries. For the well-known Socratic injunction-"Man, know thyself"-is as relevant to the Africans today as it was to the ancient world of the renowned philosopher, Socrates.

Perhaps the study of African culture is even more important for appropriate management and development issues in Africa than technology and economic theories as formulated in the West.

\section{Contemporary African Cultural Values for Human Resources Practice}

Africa is not a single unified nation but characterised by diversity, contrast and contradictions. The peoples of Sub-Saharan Africa are of diverse and differing racial, tribal and ethnic cultures. They are differently exposed to Western influences and material cultures and values. Despite these differences, the people in this area seem to have much in common in their cultures, values and social structures. They share many things in their outlook and ways of life such as family orientations, traditional conflict resolutions, respect for 
elders etc. It is this ill-defined assortment of similarities that we have ventured to call contemporary African cultural values.

\section{Family Relations and Social Systems}

In Sub-Saharan Africa, the extended family (with grandparents, uncles, aunts and cousins, and with the father's additional wives and their children) is an economic unit that has to care for itself. Families are collectives sharing a common kinship lineage and living and collaborating in a village, for common security in the face of threats by nature and by man. According to Quere (1986), the family plays fundamental and globalizing role in traditional African society by the norms and values it imposes and carries out. It holds an economic dimension since the family constitutes an excellent unity of production, distribution and means of consumption. The family is conceived of as a large number of kinship groups. Kinship groups extend from the past over the present to the future, only some members are currently alive, others are dead ("ancestral spirits") and countless are still to be born. Naming children after their grandparents stands for linking generations. The ones just born have very close relations to the ones who are about to go. This keeps the family context constant and signifies a circular perception of time (Behrend, 1988). Every member of the family is taught to accept his place in the group and to behave in a way to bring honor to it.

Within the family positions are classified and expressed by exact terms. In some African societies, mother's brother is called differently from father's brother. Simultaneously, different responsibilities are assigned to different position: the mother's brother may have specific responsibilities for his sister's children, which her husband or her husband's brother cannot carry. Polygamy (one husband with more than one wife) bound by a common lineage is the sole authority and complicates family relationships further. The extended family provides each member with shelter and food, regardless of personal contribution. The elders closely scrutinize the behavior and manner of the individual member of the family.

Common blood ties create common obligations. Relatives should be supported, in sickness or health, success or failure. Exchange practices stress "giving" more than "taking". When a community needs to make an investment (e.g. for a school building), everybody is called to donate. Each contribution is respected and welcome, no matter whether it is a substantial amount of money or a chicken. A family member fulfils his obligation not by acquiring for himself but by given to other members.

The extended family systems (see Table 4) provide the basis for social transfer in Africa. According to Dia (1996), 'social transfers are both monetary and in kind. Work on family farms and expenditures for ceremonies are provided to extended family members.' Social transfers are an integral part of the local culture, even among the religious leaders, fraternal and religious organizations, and the educated and among the rich. In addition to the redistributive and prestige-enhancing functions of the social transfers, extended family provides a potent, efficient, finely turned, and need-based social insurance systems. The insurance provided by extended family transfer systems responds to both the customary and the unusual needs of the lineage, providing old age and catastrophic insurance. It also substitutes for a society welfare system, increase the sense of security of the individuals and society, and encourage a more egalitarian distribution of access to schooling and health services (Takyi-Asiedu, 1993:95). 
Table 4. Number of dependants on one's salary across-cultures

\begin{tabular}{|c|c|c|c|c|c|c|c|c|}
\hline \multirow{2}{*}{$\begin{array}{l}\text { No. of } \\
\text { dependants }\end{array}$} & \multicolumn{2}{|c|}{ France } & \multicolumn{2}{|c|}{ Italy } & \multicolumn{2}{|c|}{ Scotland } & Holland & Nigeria \\
\hline & no. & $\%$ & no. & $\%$ & no. & $\%$ & no. $\%$ & no. $\%$ \\
\hline $1-2$ & 30 & $58.8 \%$ & 70 & $67.3 \%$ & & $54.4 \%$ & $84 \quad 61 \%$ & $27 \quad 10 \%$ \\
\hline $3-4$ & 13 & $25.5 \%$ & 23 & $22.1 \%$ & 27 & $33.3 \%$ & $51 \quad 37 \%$ & $28 \quad 10 \%$ \\
\hline $5-6$ & 7 & $13.7 \%$ & 7 & $6.7 \%$ & 10 & $12.3 \%$ & $2 \quad 1 \%$ & $10839 \%$ \\
\hline$>6$ & 1 & $2.0 \%$ & 4 & $3.9 \%$ & 0 & $0.0 \%$ & $2 \quad 2 \%$ & $11741 \%$ \\
\hline Total & 51 & $100 \%$ & 105 & $100 \%$ & 81 & $100 \%$ & $143100 \%$ & $280100 \%$ \\
\hline Mean & 2.2 & & 2.10 & & 2.37 & & 3.13 & 7.31 \\
\hline
\end{tabular}

Goals printed in bold letters, the difference between the countries is significant at the .01-level.

Source: Author's own.

Given the central role of the extended family (Table 4), it is clear that the sanctions of kin carry considerable weight and that heavy pressure to conform can therefore be exerted on those in position and power (Blunt, 1992:244). The extent to which leaders conform to the above traditional principles is a fairly robust predictor of their success or failure.

Within the African societies, individualism is suppressed, and from his early age a person is taught to accept his place within the kinship organization as determined by his age. Only those who have attained sufficient age and experience have a voice in in-group affairs. On the culture dimensions of Individualism versus Collectivism identified by Hofstede $(1980,1991)$ and validated by Iguisi (1993), African societies score strongly collectivistic and. European societies score individualistic.

Achievements within the African traditional culture were usually attributed to group efforts. Strong emphasis was put on balancing aggression between the members: individual assertiveness was disapproved of or ignored. The late Tanzania President Nyerere described traditional African family-hood ("Ujamaa") as, among other things, co-operative and non-competitive (Cameron, 1975). This suggests that Sub-Saharan African cultures are not only traditionally collectivistic but also, on another of the cultural dimensions identified by Hofstede (1980, 2007), masculinity versus femininity, traditionally more feminine than masculine see Table 2 (Hofstede and Iguisi, 1993).

The organization of traditional African life was a closed circuit between humans and their environment oriented towards harmony. The system was small in size, depended on local knowledge and maintained homogeneity of members. When conditions changed, communities tried to absorb the new elements by means of dynamic symbols and rituals (dancing, drumming, and story telling). In this way, the balance of the social system was protected from major disturbances. Responses to recognized environmental changes were tailor-made to their occurrence (Kiggundu, 1993). 
In the African cultural pattern, there still tends to be a strong emphasis on the settling of disputes and restoration of harmonious personal relationships, on which it places a high value. There is special respect shown to people like the doctor and rain-maker whose skills are seen as a mixture of 'science' and spiritualism, and who work at restoring or maintaining good relations between ancestors and descendant or between man and nature (Onyemelukwe, 1973:26). In legal as well as in political matters Africans tend to seek unanimity and generally prepared to engage in seemingly interminable discussions. In the same spirit, the judgments handed down seek to establish a broad area of consent. The goal is to keep personal relationships as harmonious as possible. Many African communities have highly developed political organizations, including kings and chiefs as well as attendants wielding varying degrees of authority. The significant point is that this political hierarchy is for the service of the society. Therefore, if there is a dispute of which the parties cannot solve, elders will try to mediate. If the elders fail to succeed (and they rarely do), the matter is finally taken to the chief or King of the community, and with the assistance of his deputies, question the disputants, warn, advice and finally tell them the final decision by which they must abide. In difficult cases, the decision was traditionally referred to ancestral spirits who revealed their response through oracles ${ }^{\mathrm{a}}$.

In most African traditional societies, it is a customary procedure that dispute be brought to an end by songs and dances, signifying that the two parties have agreed to maintain harmony and understanding. In Dia's observations, this is the opposite of the spirit that imbues law in the Western societies, where the court interprets the law and pronounces a sentence to which the parties have to summit (Dia, 1993).

\section{Socioeconomic Systems}

One form of social association in most of Sub-Saharan Africa is the indigenous systems of savings and credit. This system has been described in ethnological literature but rarely has been systematically studied (Seibel and Damachi, 1982; Boon, 2005). These indigenous group-based savings and credit activities unite local people to identify their needs and mobilize their own resources. This system provides for leisure activities such as, baptisms, weddings, death or other occasions. These activities have a modern, a traditional or a mixed content, but fundamentally the members of the associations tend to let traditional cultural values predominate. The preference for these cultural features in modern formal organizations is obvious in the ways conflicts are settled and the various rituals celebrated (baptisms, weddings, deaths etc).

\footnotetext{
a Ancestral spirits needed to be kept benevolent. They were always integrated into the "here and now'. During celebrations, food for them was put outside village boundaries. At night they were expected to come as animals and eat from it. If the food had not been touched in the morning, it was a sign of their ill will.
} 
In addition to leisure and consumption activities, the system encourage among their association members the principle of rotating loans which allows each member in turn to receive the amount contributed by the other members. In the words of Gabin, this principle is based on verbal agreement among several people linked by friendly or professional ties, the objective being to accumulate savings from the membership dues paid regularly. The final aim is social mutual assistance (Gabin, 1997).

By subscription to this system of social association, members then provide for themselves what governments and their formal organizations cannot provide them (Ijere, 1988b; Nweze, 1990; Akinsiku, 1981; Gabin, 1997; Kaseke, 1997).

\section{Modernity versus Traditions in Africa}

However, as will be seen in other areas, there is a gradual transformation of the Sub-Saharan African societies from a purely collectivist one to a mixture of collectivist and individualist. The gradual increase in the number of western-trained Africans is changing this communal society that once existed, to the point that many 'western-trained' African managers and elites are openly declaring themselves individualists who have little or do not have any more regard for that tradition, which emphasized collectivism or communalism.

The work of Odubogun (1992) shows that there is an ongoing gradual transformation of African societies from a purely traditional one to a mixture of traditional and modernity.

According to Odubogun, the gradual increase in the number of Western-trained Africans have led to this change in traditional society, to the point that many 'Western-trained' Africans are openly declaring themselves Westernized and individualists who no longer have regard for traditional practices emphasizing collectivist values. Such people find it more beneficial and convenient to seek their own self-interest rather than the collective interest. The problem lies not in the gradual modernity or transformation, but in the difficulties arising from coexistence of the traditional ways of collectivist values and Western-derived individualist values. The problem emphasizes the fact that most Westernized "liberated" Africans often at convenient moments revert back to traditional values, especially if it benefits them to do so. In which case one cannot easily predict which end of the continuum they fall, as their behavior patterns do not seem to reflect values but opportunistic behavior. For example, most African leaders and managers attempt to satisfy traditional norms with Western thinking. In situations where combinations of cognitive and social skills are acquired, individualist and collectivist values tend to clash. This becomes quite confusing for the African managers and leaders, and impairs building an authentic universally accepted managerial leadership style in African organizations.

It will be convenient therefore, to say that today; western mode of life is flourishing in nearly every part of Africa. That such western mode of life is in practice not the case is revealed particularly clearly in Africa's cities. According to the tenets of sociology of development, urbanized individuals become increasingly detached from the 'traditional' personalized relations characteristics of social life in normal areas. In the cities, high population densities, the mixing of ethnic groups and the intermingling of professions should all favor more individualized social conditioning. Yet, what occurs is usually the reverse: urban dwellers 
appear to replicate the type of informal and personalized social rapport, which is the hallmark of 'traditional' African life. City quarters tend to mirror regional or ethnic divisions. Welfare organizations and traditional savings and banking (tontine) systems are widely practiced-in part, of cause, because they offer some form of (morally building) social protection, which no formal organizational arrangements or management could offer or equal.

The arguments, as outlined in this paper is not that Africa now need "to return" to its ancient, more indigenously culture. It is on that which deals with Africa's present managerial crisis as a crisis of modernity, leaving open the search for a more feasible model of management. There has, of course, been no shortage of proponents of a return to pre-colonial roots, to some form of African 'authenticity', as a way of constructing appropriate management practices in Sub-Saharan Africa congruous with the local environment of management.

Can a workable management encompass' growth-positive' cultural values? Can there be culturally feasible management structures, which can function effectively and for the common weal? Is feasible management based on African cultural values and traditions possible? These are difficult questions but they will need to be addressed if we are to make any progress in understanding the relationships between cultural values and modern management practices in Sub-Saharan Africa.

An African scholar (Tshiyembe, 1998) has reflected constructively on the issue of culture for political development. In his recent article in Politique Africaine, he upbraided francophone Africanists for their failure to conceptualize African politics other than in eurocentric terms. His view is that the two dominant paradigms of the post-colonial African state-one stressing the adaptation of the imported model, the other the neo-patrimonial conservation of the European state-neglect to take into account the centrality of cultural values in the social and political imagination of most Africans. Like in my study, then, Tshiyembe emphasizes the extent to which culture is the foundation of African political (in my case managerial) thought. Although the notion that culture is fundamental to African modern and appropriate development is not new, what is new is the argument that culture is creatively compatible with managerial modernity. The emphasis on cultural values is not an argument about the "backwardness" of African management development, but one about the necessary re-echoing of appropriate management in Africa organizations congruous with the local cultures and management environment.

\section{Cultures and Human Resources Practice in Africa}

Culture is always a collective phenomenon, because it is at least partly shared, constructed and reconstructed by people who live or lived within the same social environment, which is where it was learned. It is that which individuals inherit or acquired in their early child-hood in the family, reinforced by schools, work-places, social organizations, government and different religious institutions.

As far as Sub-Saharan Africa is concerned, the starting point in changing perceptions about human resouce management is to harmonize cultural values with western management assumptions. The question to ask is how do we harmonize cultural values with modern management practice of HR? This paper therefore 
suggests the followings areas for adequate empirical research and analysis and where possible for adoption or adaptation into the practice of human resource management in African organizations.

i. Organizational Recruitment

ii. Managerial Leadership (paternalism)

iii. Organizational Induction

iv. Managerial Training

v. Organizational Discipline

vi. Motivation and Reward Systems

vii. Welfare

\section{i. Human Resources (Recruitment)}

The strength in African traditional system stems from reliance on the intimate knowledge of the person being recruited or selected for a job, his loyalty, and family background. In traditional community, emphasis is laid upon the collective interest of the people and not upon undue competition. The people in an assembly are addressed as a community with one interest and one purpose. Tasks that have to be done nearly always call people that can perform such tasks successfully. Specialized jobs call for people who are well known for their feasible specialized skills. When the choice has to be made about selecting the right candidate for succession to a thrown in some traditional societies, an oracle or the ancestral spirits are consulted so as to invest the choice with the symbol of divine authority. This method can be equated to the "modern" method of using industrial psychologist.

By harmonizing some of the essences of traditional cultural values with management in the selection of staff for African organizations, some of the banes of employer / employee relationships would have been demolished, disputes would be rare and the recruited work-force will function like an integrated traditional community.

\section{ii. Managerial Leadership (Paternalism)}

African society generally is very paternalistic and hierarchical. Little prone to individualism, it tends to be egalitarian within the same age group but hierarchical in group-to-group relations, with marked subordination of the younger members.

One of the actions that could be taking to effect integration of African cultural values into modern management could be the adoption of paternalistic managerial leadership (see Table. 1). Under such leadership, the responsibility for making rules exclusively vested in the leader to whom subordinates are expected to give absolute loyalty as children are assumed to give their father. The traditional concept of (paternalistic) leadership as enshrined in the family is closer to the prevalence culture in Africa and is more likely to produce a higher managerial effectiveness and workers' productivity. The paternalistic component confers on management the right to give orders and exact obedience and impose sanctions. But in the 
traditional family structure, authority is not only exercised for productive ends only; the leader who gives order is as well concerned with the wellbeing of subordinates and their families.

Paternalistic and hierarchical structures have often been regarded by Westerners-who highly value assertiveness, individual freedom, and responsibility-as running counter to productivity and creativity. However, this is not always borne out by fact of history. First, in most rural areas the type of aggregation (lineage, kinship) and the size of the unit (large extended family or small nuclear one) will determine how land and labor is allocated. A managerial leadership founded on dependency and paternalism may prove just as creative as any other may. Indeed, the impulse to bring oneself to the notice of the "King" may be a more powerful incentive than self-achievement. Even if paternalism and dependency slow the pace at which an entire population verges and evolves, need not hinder the ultimate objective of appropriate management and economic development.

\section{iii. Organizational Induction}

Induction into modern organization could be substituted for with initiation rituals in the traditional African community. Initiation has rites and processes for assimilating new employee into an organization. There are prescribed roots that should be followed before one could qualify for induction.

The induction of new employee into an organization or promotion of employee into higher position of responsibility and authority should include an oath-taking ritual. With oath-taking ritual, the religious element in the culture is involved. Oath-taking features in almost all aspects of social relationship in traditional African communities.

Could this cultural value of induction be correlated and harmonized with modern management in Africa? Indeed in some circumstances such as appointing to important public offices such as those of President, Ministers, Judges etc., oaths of allegiance and of offices are administered through the swearing on the Bible or Koran. Therein lie some elements of the solemnity of induction. The effect of an oath, when adapted in modern management and properly administered in the traditional African way, with the necessary references made to the ancestral spirits and family or community shrines, is that the person, fearing the consequences of default, tries to behave always in accordance with what he has agreed to during the oathtaking ritual. In modern management setting, the Bible, Koran or any other religious holy books could be used for this undertaking by those who adhere to these religions, but for the non-Christians or Muslims, the traditional African deities priest could be invited to administer the oath-taking in the presence of the chief executive and other management officials (Ahiauzu, 1989).

When this ceremony of induction is adapted and properly performed in modern, as it is done in traditional African settings, the degree of commitment, allegiance, and honesty of organization members with regards to organization and the achievement of its objectives will certainly increase. Oath-taking certainly should be conducted from time to time in the career of all within the management positions. 


\section{iv. Training}

In traditional African communities, training involves a long-apprenticeship. The trainee is trained not only on the job but his whole personal character is also developed at the same time. Part of the training objective is that the trainee should be useful to himself and as well as meet the corporate goals of the community. Opportunity should be created for training and re-training organization members about modern management techniques, about growth-positive and growth-negative culture values of their societies through day releases, periodic courses, seminars and attendance in conferences. Moreover, action should be taken periodically to educate and update every member of the organization's knowledge of the history of the organization. Africans have great regard for the oral traditions that inform them of their historical origins, for when such traditions are related, very often by elders, some sort of consciousness is aroused in the young ones that generate a feeling of identity and attachment to one's "roots".

Through continuous training on modern management techniques and traditional values, the spirit of culture and tradition for modern and appropriate management in Africa could be reproduce.

\section{v. Organizational Discipline}

African culture attached great importance to discipline. This is reflected in the unwritten codes of conduct observed in almost all-traditional professions practiced by elders in accordance to the community laws. When the community is relatively small and practically all members know one another it was easy to observe behavior of one another. Indiscipline was difficult to condone; for if it violated the common laws, community had a way of dealing with it. With the family, even though extended, the members of the community were jealous of the good names of their families and would do everything to preserve the good names and not bring shame to the family. Conversely, leaders had as their objectives the wellbeing of the whole community and so they were themselves attuned to lead by example. Nonetheless, any offending member had to be disciplined irrespective of his or her status. The homogeneous community, as it were, made everyone his brother's keeper. A deviant action is regarded as one against the community in which justice has to be administered. The elders are responsible for the administration of justice who in doing so, brought to bear on their judgment the experience of their age and accumulated wisdom that went with ripe age.

This traditional principle could be applied in modern management and would check abuse of office and instill discipline in the rank and files of the organization members.

\section{vi. Motivation and Reward Systems}

In traditional African societies, there were systems of motivation and reward. In the community, values were of the kind that strengthened and maintained the stability of the community. The past is constantly invoked in the present and the present lies the future. The young in the family are constantly motivated to emulate the great deeds of their ancestors. He would be exhorted to grow up and perform the kind of great deeds of his ancestors and would be motivated to perform wonders for the good of the community and not 
just for himself alone. If he misbehaved, he would be judged to be unworthy of his forebears, i.e. the height of shame. If he performed well, he would be declared a true son of his ancestors.

What motivate persons in traditional African society differs from what motivate people in modern organization (see Table. 5). One of the ways to translate traditional values and adapt them into modern management would be to make use of non-materialistic methods of status symbols to show appreciation for hard work; e.g. inclusion of superior performers in an honor roll incorporating the history/culture of the organization, the use of letters of appreciation and citation during special awards. These should not, however, be seen as a substitute for well-articulated pay or any other motivation policy by management.

\section{vii. Welfare}

Traditionally, the welfare of each African is always the concern of every member of his community. It is observed, however, that the practice in present modern management in Africa is not far-reaching as that of traditional organizations. Traditional society, upon its communal interest provided for the unfortunate and the handicapped among its people. The extended family took care of its members but it is also a truly open society. Strangers were welcomed and unless they proved intractable or criminally inclined they were soon absorbed into the host community through inter-marriage. The aim of the traditional community is to promote the welfare of all without making exceptions or destruction. This traditional value could be adapted to modern management through the encouragement of all employees of the organization to feel that they belong; to realize that they must contribute according to their ability and that they would be rewarded according to their deserts. Africa do not need modern "ism" of philosophy for this; it is inherent in the culture and traditional background, which is feminist and welfare-oriented; not the welfare of the few and the privilege but welfare for all.

Worth stressing here is the fact that Africans, no matter their level of involvement in their modern organizations either as managers or employees, do not stop living and being directed and influenced by the larger community. Even when many acquire their education and training in the Western countries or at home in Western type institutions and over adopt Western value positions by becoming more Western than the Westerns, most, if not all still maintain their ties with the African wider community; ties which have been so rooted in their being that they are almost unbreakable. Also important is the element of maintaining permanent contact with the traditional leaders and elders of the community who ensure that their younger citizens who live and work in modern organizations do not lose touch with their culture but still maintain loyalty to it. The general situation for the average African, is that while they struggle to learn and understand the Western ways of work life and try to use techniques for problem solving prescribed by Western theories and models, they never really forget their culture and the pressure that comes from it. They are still dictated to, manipulated, coerced, and generally, influenced by groups outside their immediate work environment. They are influenced and pressured by immediate and extended family members, by non-family elders in society, by friends and peers, by local and national government, by religious groups, by ethnic groups of interest and so on. 


\section{Conclusions}

This paper has discussed the issues of the role of culture in management and a number of issues in western management theories and assumptions that are culturally conditioned. Effectiveness and appropriateness within a given culture, and judged according to the values of the culture, call for management theories and assumptions reflective of the local culture.

Experiences based on empirical evidences have shown us the problems that African nations are facing due to transplantation of Western management theories and models aliens to the African cultures. It has been shown that the different management theories of motivation, leadership, organization in the form that they have been developed in the west, do not or partially fit culturally in Africa. However, in developing theories and building models of appropriate management theories in Africa, it is unlikely to pay us to throw away all that the West has to offer. Rather, the process of human resources and appropriate management practice should be to reflect on the cultures and assumptions of Western management theories, compare Western assumptions about social and cultural values with African cultural values and rebuild the theories or models through experimentation. In doing this, there is a need for the application of anthropological concepts to the field of human resources and appropriate management theorizing in Africa in order to help understand how African organizations and institutions worked in the pre-colonial era. Certainly, Africans must have had ways of organizing their world of work. They must have had ways of exercising power and leadership at the workplace; ways of motivating and rewarding people to make them work harder. The point we are making here comes out more clearly if one draws from both oral tradition and written historical records. Before the advert of colonial administration, the old African villages and towns had effective public administrative mechanism, which the village and town heads, chiefs and kings administered. The use of anthropological concepts in this context will help in the development of appropriate and effective ways of management practice.

African scholars and practicing managers aware of the possibilities of their culture for modern management practice can hold their head erect and put their best foot forward at any feat they may attempt. They need not assume the role of black-Europeans or Americans to be good scholars or managers; there is enough strength in African cultures and traditions to enable them perform wonders in any modern organization. African scholars, managers, and practitioners' conscious of their cultures and values, more importantly, the 'growth-positive' cultural value factors in their societies can perform best in modern organizations.

This paper has shown the link between culture and management. Empirical evidences have been provided to illustrate the awareness of the African cultural values, in all ramifications and divested from the disrepute which colonialization has cast upon it, could provide for the Africans, the confidence with which they could tackle their assignment in modern managerial settings. Africans need not have inferiority complex. All the Africans need to do is cast their mind around into the cultural values of their societies they would be able to find enough help to cope with modern management; recruitment, induction, motivation, leadership, discipline, welfare and many other practices conducive to modern management practice in Africa. 


\section{References}

Ahiauzu, A. I. (1985b) "Towards a Diagnostic Approach to Motivating the Nigerian

E L (ed.) Managing Nigeria's Economic System

(Heinemann, Ibadan)

Worker" in Inanga 200-211.

Ahiauzu, A.I. (1988) "Organizational Behavior Theorizing in Africa", Journal of

Management

Education and Training, Vol.3,No. 2, (December), pp.79-85)/

Akinsiku, O.O. (1981) The Problems of Agro-Based Industries in Nsukka L.G.A. and Suggested

Solutions, B.Agric Thesis. University of Nsukka.

Behrend, H.(1988) Die Zeit Geht Krumme Wege. Frankfurt Campus.

Blunt, P.\& M. Jones (1992). Managing organizations in Africa. Berlin \& New York: Walter de Gruijter.

Boon E,M (2005). Knowledge Systems and Traditional Versus Modern Social Security Systems in Africa:

A Case Study of Ghana. In Boon, E.K \& Hens, L.(eds). Indigenous Knowledge Systems and

Sustainable Development: $\quad$ Relevance for Africa. Delhi, Kamla-Raj Enterprice.

Boon, M. (1996). The African Way: The Power of Interactive Leadership, $\quad$ Johannesburg: Z Zebra Press.

Cameron, J. (1975) "Traditional and Western education in Mainland Tanzania: an attempt at synthesis". In: Brown, G.N. \& Hiskett M. (eds.): Conflict and Harmony in Education in Tropical Africa. London: Allen \& Unwin, 350-362.

Dia, M. (1996) Africa's Management in the 1990's and Beyond: Reconciling Indigenous and Transplanted Institutions. Washington: The International Bank for Reconstruction and Development, The World Bank.

Franke R.H., G. Hofstede, and M.H. Bond (1991) Cultural Roots of Economic Performance: A Research Note. In: Strategic Management Journal, Vol. 12, 165-173.

Gabin, Kponhassia. (1997) Urban Life and Traditional Models: A Study of the Social Networks in a Secondary Town in Côte d'Ivoire-the Example of Agoville.

Herzberg F. (1966) Work and Nature of Man. New York: World Publishing.

Heszberg, F. (1968) ‘One more time: how do you motivate employees?’ Havard Business Review, January-February, 53-64.

Hofstede G. (2011), Dimensionalizing Cultures: The Hofstede Model in Context

Hofstede G. (2005) Culture Consequences: Comparing Values, Behaviour, $\quad$ Institutions and Nations. CA: Sage.

Hofstede, G. 2007. Asian management in the 21st century. Asia Pacific Journal of $\quad$ Management, 24 : 411-420.

Hofstede G. (2001) Culture Consequences ( $2^{\text {nd }}$ ed,). Thousand Oaksm CA: Sage.

Hofstede G. (1991) Cultures and Organizations: Software of the mind. London:

McGraw Hill.

Hofstede G. and M.H. Bond (1988). 'The Confucius connection: 'From cultural roots to economic growth', In Organization Dynamics, 16, pp.4-21). 
Hofstede G (1980) Culture's Consequences: International Differences in Work-Relate Values. Newbury Park CA: Sage.

Iguisi O. (2014). Cultural Vualues and Motivation in Nigeria Work Settings. . In Umit Hacioglu \& Hasan Dincer (eds). Globalization and Governance in the International Political Economy. IGI Publishing.

Iguisi O. (2012). Cultural Dynamics in African Management Practice: Leadership, $\quad$ Motivation, Recruitment and Promotion. LAP LAMBERT Academic Publishing.

Iguisi, O. (2009). Motivation-Related Values across Cultures. International Journal of African Business and Management.

Iguisi, O. (2007). Management and Indigenous Knowledge Systems: An Analysis of Motivational Values Across Cultures. In Boon, E.K \& Hens, L.(eds). Indigenous Knowledge Systems and Sustainable Development: Relevance for $\quad$ Africa. Kamla-Raj Enterprice. Delhi

Iguisi O. (1998). Supporting Entrepreneurship in New Strategic Environment (SENSE): Cultural

Perspectives to Entrepreneurial Effectiveness Across Cultures. EU- ADAPT/E-AMARC

Research Publications.

Iguisi O (1997). The Role of Culture in Appropriate Management and Indigenous

Development in Africa. Paper delivered at the African seminar on Culture Dimensions to Appropriate management and Sustainable Development in Africa.

UNESCO Publications, Paris

Iguisi O (1994). Appropriate Management in an African Culture. In: Journal of Management in Nigeria. Vol., 30 No.1, 16-24.

Iguisi O. and Hofstede G (1993). Industrial Management in an African Culture. IRIC University of Limburg Press, Maastricht.

Iguisi, O (1993). Cross-Culture Management Survey. Institute for Research on Intercultural Cooperation: University of Limburg, Maastricht-NL.

Jackson, T. (2004) Management and Change in Africa: A Cross-cultural Perspective. Routledge, London.

Jackson, T. (2005). Hybridisation of people Management Systems: Western MNCs in Africa. Ijere, N.O. (1988b) Management Potential of Self-Help Organizations. Centre for Rural Development and Cooperatives, University of Nigeria, Nsukka, Nigeria.

Jackson, T. (1999) Management of People and Organizations in South Africa and Zimbabwe Cross-Cultural Study. Working papers 99/1

Kaseke, E. (1997) Social Security in Eastern and Southern Africa Organizations, Issues and Concept in Modern and Traditional Arrangements. Journal of Social Development in Africa, vol. 121 No. 2, pp. 39-47.

Kiggundu, M. (1993) "The Challenge of Management Development in Sub-Saharan Africa". In: Blunt, $P$ et al (eds.) Managing Organizations in Africa. Readings, $\quad$ Cases, and Exercises. Berlin: de Gruyter, 169-186.

Lamb, D. (1985) The Africans. Revised edition. New York: Random House. 
Likert, R. (1961). New Patterns of Management. New York: McGraw Hill,

Likert, R. (1967). The Human Organization. New York: McGraw Hill. London.

Maslow A. (1960) Motivation and Personality. New York: Harper, 1954.-(ed.) New Knowledge in Human Values. New York: Harper, 1960

Mbigi, L. (1997) Ubuntu: The African Dream in Management, Randburg, S. Africa: $\quad$ Knowledge Resources.

McClelland, D. (1961) The Achieving Society. Princeton, N.J., Van Nostrand.

Nweze, N. J. (1990) The Role of Women's Traditional Savings and Credit Cooperatives in Small Farm Development. African Rural Social Science $\quad$ Series, Research Report Number 11.

Onyemelukwe, C. C. (1973) Men and Management in Contemporary Africa. Longman, London

Oshagbemi, T. (1988) Leadership and Management in Universities: Britain and Nigeria. Berlin: de

Ouchi, W. (1981) Theory Z: How American Business can meet the Japanese Challenge. Wesley, Addison.

Takyi-Asiedu, S. (1993) 'Some socio-cultural factors retarding entrepreneurial activity in Sub-Saharan Africa', Journal of Business Venturing, 8, 91-98.

Taylor, F.W (1911) The Principles of Scientific Management. New York: Harper and Row.

Tshiyembe, M. (1998) 'La science politique africaniste et le statut théorique de l'État Africain: un bilan négatif', Politique Africaine, 71(October) 